\title{
ANALYSIS OF OSSEOUS TISSUE TEMPERATURE DURING PREPARATION OF RECIPIENT BED FOR CYLINDRICAL IMPLANTS
}

Ivashchenko AV $₫$, Yablokov AE, Tlustenko VS, Postnikov MA, Popov NV, Tlustenko VP, Tugushev W, Cherezova NI, Mukhina AA, Belanov GN

Samara State Medical University, Samara, Russia

\begin{abstract}
In the early $21^{\text {st }}$ century, robot-assisted dental implant surgery became a popular alternative to classic implant placement protocols. Postoperative complications are often provoked by poor compliance with surgical guidelines for implant placement, resulting in the overheating of the osteotomy site. The aim of this study was to measure the temperature of osseous tissue at the dental implant site during classic and robot-assisted dental implant placement performed at different cooling modes. Avital skeletonized mandibles of Vietnamese pot-bellied pigs were used as an experimental model. The recipient bed was prepared following the classic surgical protocol. Three cooling modes were tested: no irrigation, irrigation with sterile saline at $25-30 \mathrm{ml} / \mathrm{min}$ and standard $75 \mathrm{ml} / \mathrm{min}$ irrigation recommended by the standard surgical protocol. The temperature of the isotonic solution was $25^{\circ} \mathrm{C}$. The study showed that both classic and robot-assisted dental implant placement techniques are safe if there is sufficient irrigation and good compliance with the surgical protocol.
\end{abstract}

Keywords: robot-assisted system, bone heating, dental implant placement

Author contribution: Ivashchenko AV, Postnikov MA collected and analyzed clinical data; Tlustenko VP did organizational work and conducted the experiment; performed systematic analysis; Popov NV performed statistical analysis of the obtained data; Yablokov AE did organizational work and conducted the experiment, collected and analyzed clinical data; Tlustenko VS analyzed clinical data. Tugushev W, Cherezova NI, Mukhina AA did organizational work and conducted the experiment; Belanov GN — sistematic analysis.

Compliance with ethical standards: the study was approved by the Ethics Committee of Samara State Medical University (Protocol 209 dated February 3, 2021).

$\square$ Correspondence should be addressed: Alexander V. Ivashchenko

Chapaevskaya, 89, Samara, 443099; s1131149@yandex.ru

Received: 08.02.2021 Accepted: 23.03.2021 Published online: 08.04.2021

DOI: $10.24075 /$ brsmu.2021.013

\section{ОЦЕНКА ТЕРМОМЕТРИЧЕСКИХ ДАННЫХ КОСТНОЙ ТКАНИ ПРИ ФОРМИРОВАНИИ ВОСПРИНИМАЮЩЕГО МАТЕРИНСКОГО ЛОЖА ПОД ЦИЛИНДРИЧЕСКИЕ ДЕНТАЛЬНЫЕ ИМПЛАНТАТЫ}

А. В. Иващенко $\bowtie$, А. Е. Яблоков, В. С. Тлустенко, М. А. Постников, Н. В. Попов, В. П. Тлустенко, В. В. Тугушев, Н. И. Черезова, А. А. Мухина, Г. Н. Беланов

Самарский государственный медицинский университет, Самара, Россия

Установка дентальных имплантатов с применением механотронных устройств получила широкое применение в начале XXI в., наряду с классическим имплантологическим протоколом. Осложнения нередко обусловлены несоблюдением стандарта хирургического протокола проведения дентальной имплантации и, как следствие, повышением фокуса температуры в месте сверления костной ткани челюстей. Целью работы было оценить фокус температуры костной ткани в области установки дентального имплантата, проводимой по классической методике и с применением механотронной системы с различной степенью охлаждения. В качестве экспериментальной модели использовали авитальную скелетированную нижнюю челюсть поросенка вьетнамской вислобрюхой породы. В соответствии с классическим хирургическим протоколом было сформировано воспринимающее материнское ложе. Исследование проводили в трех режимах: при отсутствии подачи изотонического раствора, при незначительном его объеме (25-30 мл/мин) и при орошении раствором в соответствии с хирургическим протоколом (75 мл/мин). Температура подаваемого изотонического раствора составляла $25^{\circ} \mathrm{C}$. По результатам исследования, и классическая методика установки цилиндрических дентальных имплантатов, и их инсталляция с применением механотронной системы безопасны при условии соблюдения хирургического протокола и с достаточным объемом подаваемого изотонического раствора.

Ключевые слова: механотронная система, нагревание кости, дентальная имплантация

Вклад авторов: А. В. Иващенко - сбор и анализ клинических данных; В. П. Тлустенко - подготовка клинического материала, систематический анализ; М. А. Постников - сбор и анализ клинических данных; Н. В. Попов - обработка и анализ полученного материала; А. Е. Яблоков подготовка клинического материала, сбор и анализ клинических данных; В. С. Тлустенко - анализ клинических данных; В. В. Тугушев - подготовка клинического материала; Н. И. Черезова - подготовка клинического материала; А. А. Мухина — подготовка клинического материала. Г. Н. Беланов систематический анализ.

Соблюдение этических стандартов: исследование одобрено этическим комитетом Самарского ГМУ (протокол № 209 от 3 февраля 2021 г.).

$\triangle$ Для корреспонденции: Александр Валериевич Иващенко ул. Чапаевская, 89, г. Самара, 443099; s1131149@yandex.ru

Статья получена: 08.02.2021 Статья принята к печати: 23.03.2021 Опубликована онлайн: 08.04.2021

DOI: 10.24075/vrgmu.2021.013

Robot-assisted dental implant surgery has become a popular alternative to classic implant placement protocols [1, 2]. The key risk factor for postoperative complications is poor compliance with surgical guidelines for implant placement, resulting in the overheating of the osteotomy site $[3,8]$. Heating to over $48{ }^{\circ} \mathrm{C}$ causes a thermal burn to stromal dental tissue and protein denaturation. This prevents osseointegration between the implant and the bone and eventually leads to implant failure $[4,11]$.
The primary cause of an osseous burn during drilling is the wrong choice of the bone cutting and cooling modes (drilling speed $>1,200 \mathrm{rpm}$, saline irrigation rate $<70 \mathrm{ml} / \mathrm{min}$ ) $[5,9,10]$. During robot-assisted implant placement, saline irrigation must be performed at $100 \mathrm{ml} / \mathrm{min}$. Drill manufacturers (Dentium, Israel; MIS, Israel; etc.) recommend that the maximum number of drill uses during surgery should be limited to 40-45 [12-15]. Discrete irrigation of the surgical field during recipient bed preparation is not allowed in both classic or robot-assisted dental implant surgery [6-8]. 
The aim of this study was to measure the temperature of osseous tissue at the dental implant site during classic and robot-assisted dental implant placement performed at different cooling modes.

\section{METHODS}

The study investigated the response of the alveolar bone to osteotomy and was carried out in 15 Vietnamese pot-bellied pigs. Dental implants used in the study were cylindrical. The recipient bed was prepared by drilling using an optic implant handpiece fixed in the robotic arm; the drilling speed was 800 to $1,500 \mathrm{rpm}$.

In all 3 experimental groups, irrigation of the osteotomy site was performed according to the guidelines for classic dental implant surgery. Implants were inserted at $30-45 \mathrm{Ncm}$ torque. A total of $303.6 \times 8.0$ mm cylindrical dental implants (Dentium ${ }^{\oplus}$; Israel) were installed.

The animals were divided into 3 groups based on the drilling speed and the type of surgical instrument (Table 1).

The choice of implant placement sites was based on the similarity between jaw bone density in humans and the animals used in our experiment.

Before proceeding to the main part of the study, we computed the maximum optimal temperature during osteotomy for implant placement in ANSYS 19.2 (Cadfem Company; USA) (see Fig.).

The temperature of the bone matrix during osteotomy was modeled at 3 sites: the site of bur tip/bone contact, in the apical alveolar area of the prepared recipient bed and in the recipient bed immediately after removing the bur.

While modeling the temperature during osteotomy, the pressure of the drill on the bone and drilling time were assumed to be constant.

Our assessments of thermodynamic osseous tissue states confirm that an increase in the drilling speed to $1,500 \mathrm{rpm}$ provokes a proportional rise in $\mathrm{t}^{\circ} \mathrm{C}$ to the critical threshold of $60.2^{\circ} \mathrm{C}$, given that other drilling parameters remain unchanged. An increase in the drilling speed to $1,500 \mathrm{rpm}$ results in the maximum temperature gradient rising from $37.6^{\circ} \mathrm{C}$ to $60.2^{\circ} \mathrm{C}$ (i.e., by $22.6^{\circ} \mathrm{C}$ ).

Three cooling modes were tested: no irrigation, irrigation with sterile saline at $25-30 \mathrm{ml} / \mathrm{min}$ and standard $75 \mathrm{ml} / \mathrm{min}$

Table 1. Bone cutting modes during recipient bed preparation irrigation recommended by the standard surgical protocol. The temperature of the isotonic solution was $25^{\circ} \mathrm{C}$.

We also studied the response of porcine mandibular bone tissue to robot-assisted osteotomy using the device proposed in [16]. For the "robotic" part of the experiment, similar cylindrical dental implants (Dentium; Korea) were installed using a Surgic XT Plus unit with an optic implant handpiece (Japan). The following cooling modes were tested: $75 \mathrm{ml} / \mathrm{min}$ irrigation with sterile saline recommended by the standard surgical protocol, $30 \mathrm{ml} / \mathrm{min}$ irrigation and no irrigation. The temperature of the isotonic solution was $25^{\circ} \mathrm{C}$.

The pilot drill was installed in the optic handpiece; the latter was fixed in the robotic arm. Using the joystick control, the surgeon positioned the drill at the drilling site the preoperative road map. Then, the protocol for automated bone drilling was activated. Once the drilling was finished, the robotic arm retrieved the pilot drill from the mouth cavity and the pilot drill was replaced with the bed formation drill.

Temperature was measured using a Testo 104-ir infrared probe thermometer (Testo AG; Germany). Prior to the experiment, the skeletonized porcine mandible was exposed to distilled water $\left(t=45^{\circ} \mathrm{C}\right)$ for $10 \mathrm{~min}$. The temperature of the osteotomy site before drilling was $36.8^{\circ} \mathrm{C}$.

The majority of the installed implants were in quadrants 3 (6 implants, 60\%) and 4 (4 implants, $40 \%$ ) in group 1; quadrants 3 (7 implants, 70\%) and 4 (3 implants, 30\%) in group 2; quadrants 3 (5 implants, 50\%) and 4 (5 implants, 50\%) in group 3.

During the experiment on the mandibular bone tissue of pigs, we took temperature measurements of the bone matrix at the osteotomy site. For the cooling mode 3, the peak temperature was as high as $61.5^{\circ} \mathrm{C}$. For the cooling mode 2 , the maximum temperature was $52^{\circ} \mathrm{C}$. The optimal temperature $\left(39.1^{\circ} \mathrm{C}\right)$ was achieved in the cooling mode 1.

Prior to the experiment, the animals' body temperature was taken, showing an average of 38.5 to $39.1^{\circ} \mathrm{C}$.

Table 2 shows the drilling speed, the peak temperature during drilling and the duration of drilling at different cooling modes.

The average temperature at the osteotomy site during recipient bed preparation was $39.1^{\circ} \mathrm{C}$. For our experimental animals, this value was close to normal temperature. Bur temperatures over $60^{\circ} \mathrm{C}$ during osteotomy resulted in the peak bone temperature well above the physiological norm.

\begin{tabular}{|c|c|c|c|c|}
\hline Group & Instrument & Drilling speed, rpm & $\begin{array}{l}\text { Number of installed dental } \\
\text { implants }\end{array}$ & $\begin{array}{l}\text { Implant sites and number } \\
\text { (in brackets) }\end{array}$ \\
\hline \multirow{5}{*}{1} & Lindemann guide drill & 800 & \multirow{5}{*}{10} & \multirow{5}{*}{$\begin{array}{l}3.5-2 \\
4.6-3 \\
3.6-2 \\
3.2-1 \\
4.1-1 \\
3.3-1\end{array}$} \\
\hline & Lindemann pilot drill & 800 & & \\
\hline & Harvest drill & 800 & & \\
\hline & Cortical drill & 600 & & \\
\hline & Transfer piece & $30-45 \mathrm{Ncm}$ & & \\
\hline \multirow{5}{*}{2} & Lindemann guide drill & 1,200 & \multirow{5}{*}{10} & \multirow{5}{*}{$\begin{array}{c}3.4-2 \\
4.5-1 \\
3.3-3 \\
3.2-1 \\
4.2-2 \\
3.1-\end{array}$} \\
\hline & Lindemann pilot drill & 1,200 & & \\
\hline & Harvest drill & 1,200 & & \\
\hline & Cortical drill & 1,000 & & \\
\hline & Transfer piece & $30-45 \mathrm{Ncm}$ & & \\
\hline \multirow{6}{*}{3} & Lindemann guide drill & 1,500 & \multirow{6}{*}{10} & \multirow{6}{*}{$\begin{array}{l}3.6-2 \\
4.2-1 \\
3.3-2 \\
4.2-1 \\
4.5-3 \\
4.6-1\end{array}$} \\
\hline & Lindemann & 1,500 & & \\
\hline & pilot drill & 1,500 & & \\
\hline & Harvest drill & 1,500 & & \\
\hline & Cortical drill & 1,200 & & \\
\hline & Transfer piece & $30-45 \mathrm{Ncm}$ & & \\
\hline
\end{tabular}




\section{ORIGINAL RESEARCH I DENTISTRY}

A

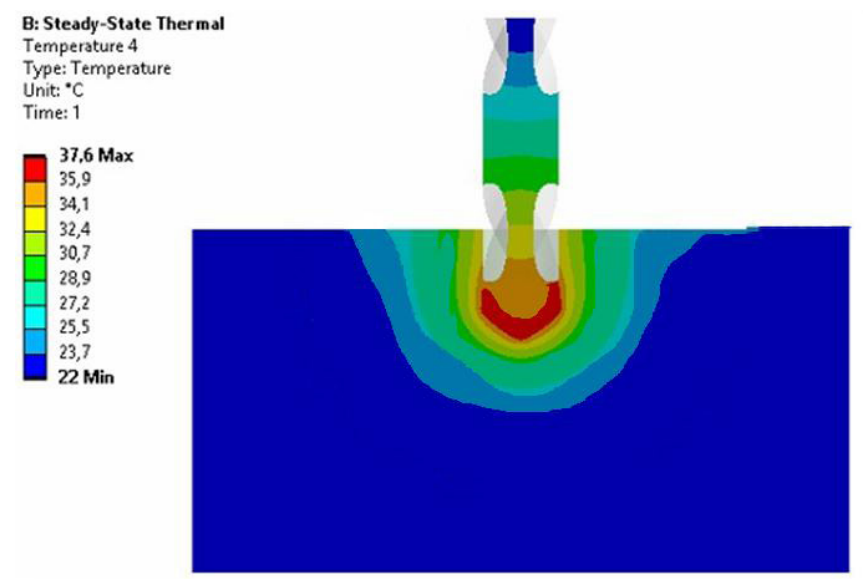

Temperature 4

Type:Temperature

Time:

C Dicops of Steady-State Thermad Type: Temogeretur

Type: Tempers
Unin: "c
Tine 1

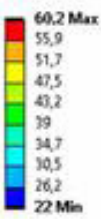

B

C: Copy of Steady-State Ther mal

Temperature 5

Type: -

Time: 1

51,9 Max

48,6
45,3
42

42
38,6

35,3

35,3
32
28,7
25,3

25,3
22 Min
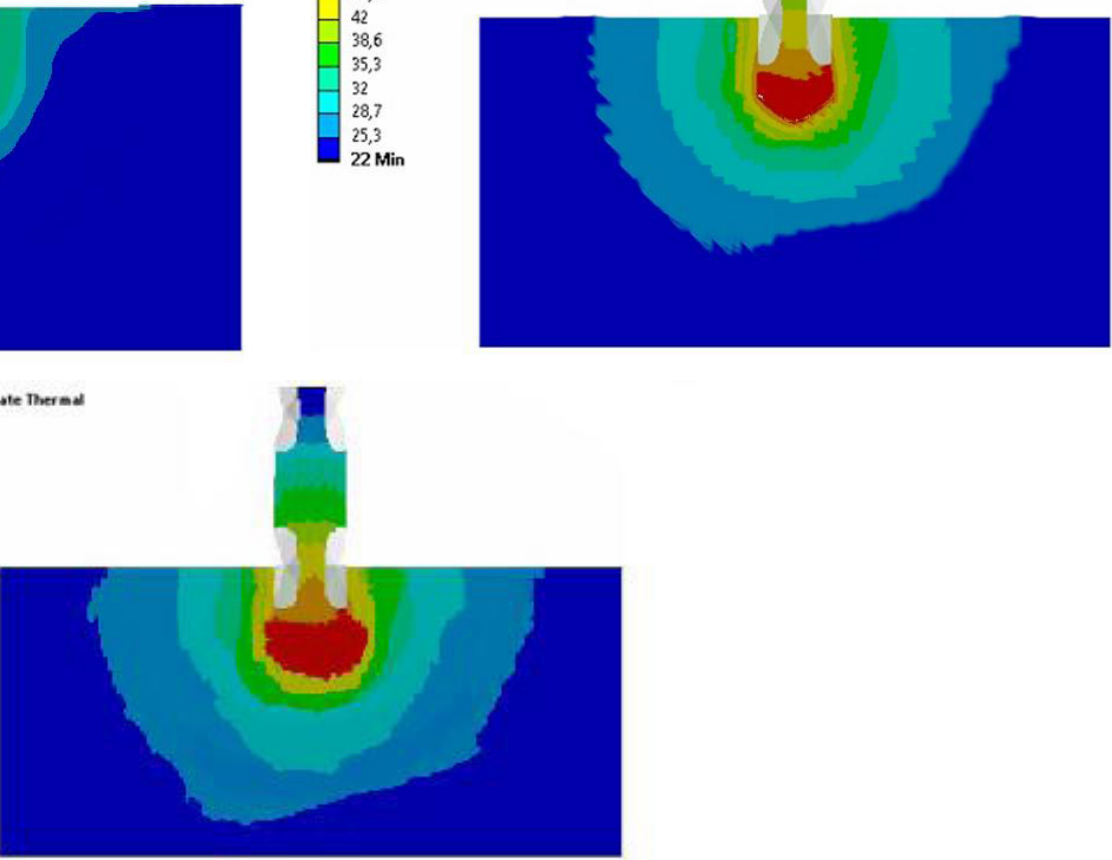

Fig. Modeled temperature during osteotomy for dental implant placement. A. Temperature gradient from $22^{\circ} \mathrm{C}$ to $37.6^{\circ} \mathrm{C}(800 \mathrm{rpm})$. B. Temperature gradient from $22^{\circ} \mathrm{C}$ to $51.9^{\circ} \mathrm{C}(1,200 \mathrm{rpm})$. C. Temperature gradient from $22^{\circ} \mathrm{C}$ to $60,2{ }^{\circ} \mathrm{C}(1,500 \mathrm{rpm})$

The relative reduction in the rate of negative outcomes in the main vs control groups, i.e relative risk reduction, was $400 \%$. This value, along with the $95 \% \mathrm{Cl}$, means that the effect is clinically significant (Table 3).

RESULTS

The temperature of the osteotomy site in the mandible rose to $41.3^{\circ} \mathrm{C}$ from the initial value of $36.8^{\circ} \mathrm{C}$ after 5 seconds of drilling in

Table 2. Peak temperature during osteotomy for dental implant surgery at different cooling modes

\begin{tabular}{|c|c|c|c|}
\hline \multirow{2}{*}{ Cooling modes } & \multicolumn{3}{|c|}{ Drilling parameters } \\
\cline { 2 - 4 } & Drilling speed $(\mathrm{rpm})$ & Bone temperature at the osteotomy site $\left({ }^{\circ} \mathrm{C}\right)$ & $39.1 \pm 0.22$ \\
\hline Mode 1 & 800 & $52 \pm 0.37$ & Drilling time $(\mathrm{s})$ \\
\hline Mode 2 & 1,200 & $61.5 \pm 0.43$ & 45 \\
\hline Mode 3 & 1,500 & 45 \\
\hline
\end{tabular}

Table 3. Efficacy of dental implant surgery according to evidence-based medicine criteria

\begin{tabular}{|c|c|c|c|}
\hline \multirow{2}{*}{ Group } & \multicolumn{3}{|c|}{ Positive clinical outcome } \\
\hline & Yes & No & Total \\
\hline Main & 5 & 0 & 5 \\
\hline Control & 15 & 0 & 15 \\
\hline RO & \multicolumn{3}{|c|}{$100.00 \%$} \\
\hline RNO & \multicolumn{3}{|c|}{$20.00 \%$} \\
\hline $\mathrm{RR}$ & \multicolumn{3}{|c|}{$500.00 \%$} \\
\hline RRR & \multicolumn{3}{|c|}{$400.00 \%$} \\
\hline CAP & \multicolumn{3}{|c|}{$80.00 \%$} \\
\hline NNT & \multicolumn{3}{|c|}{1.3} \\
\hline Odds (main group) & \multicolumn{3}{|c|}{-} \\
\hline Odds (control group) & \multicolumn{3}{|c|}{0.3} \\
\hline OR & \multicolumn{3}{|c|}{-} \\
\hline
\end{tabular}

Note: $\mathrm{RO}$ — rate of outcomes; RNO — rate of negative outcomes; RR — relative risk; RRR — relative risk reduction; NNT — number of patients that must be treated to prevent 1 negative outcome; OR - odds ratio. 
the absence of irrigation during the classic dental implant placement procedure. Irrigation at $30 \mathrm{ml} / \mathrm{min}$ during $5 \mathrm{~s}$ of drilling resulted in a lower temperature at the recipient bed site $\left(39.4^{\circ} \mathrm{C}\right)$. With irrigation at $75 \mathrm{ml} / \mathrm{min}$, the bone tissue temperature was $36.9^{\circ} \mathrm{C}$.

During recipient bed preparation, which involved bone drilling for $10 \mathrm{~s}$, the bone matrix was heated to $51.5^{\circ} \mathrm{C}$ in the absence of irrigation, $43.2^{\circ} \mathrm{C}$ at $<30 \mathrm{ml} / \mathrm{min}$ irrigation and $39.6^{\circ} \mathrm{C}$ at $75 \mathrm{ml} / \mathrm{min}$ irrigation recommended by the standard surgical protocol. Heating to over $45^{\circ} \mathrm{C}$ causes irreversible changes to bone matrix.

Similar to the classic surgical protocol applied in the first part of the study, the robot-assisted protocol involved placement of cylindrical dental implants in the skeletonized portion of the mandible. The initial temperature of the mandible was close to human body temperature $\left(36.8^{\circ} \mathrm{C}\right)$. In the absence of irrigation, the bone temperature at the osteotomy site rose to $42.4^{\circ} \mathrm{C}$. When irrigation of the osteotomy site was delivered at $<30 \mathrm{ml} / \mathrm{min}$ during 5 seconds of bone drilling, the temperature of the osseous tissue at the osteotomy site was $38.2^{\circ} \mathrm{C}$. With irrigation at $75 \mathrm{ml} / \mathrm{min}$, the temperature at the osteotomy site was $37.1^{\circ} \mathrm{C}$.

During the preparation of the recipient bed, which involved drilling for $10 \mathrm{~s}$, the bone matrix was heated to $53.9^{\circ} \mathrm{C}$ (in the absence of irrigation), $45.7^{\circ} \mathrm{C}$ (insufficient irrigation) and $38.9^{\circ} \mathrm{C}$ (sufficient irrigation according to the standard surgical protocol).

\section{DISCUSSION}

At present, there is no consensus on the optimal drilling speed. According to early reports, bone temperature rose proportional to the drilling speed [17]. However, later studies revealed that this was true only for the drilling speed of 10,000 rpm [18]. None of the studies revealed any significant changes in the temperature of a human cadaver bone during drilling at 345-2,900 rpm. This means that a temperature rise was dependent on drilling pressure more than on drilling speed. It was demonstrated that low-speed, minimal-pressure drilling of bovine cortical bones caused the same rise in temperature as drilling at higher speed and higher pressure. It is high drilling speed and pressure that allow osteotomy to be performed effectively [19]. At drilling speed below $250 \mathrm{rpm}$, bone tissue gets fragmented at the edge of the defect.

\section{CONCLUSIONS}

The analysis of osseous tissue thermometry data obtained during osteotomy for the subsequent placement of cylindrical dental implants revealed that both classic and robot-assisted dental implant placement techniques can be recommended for clinical use and are sage if there is sufficient irrigation and good compliance with the surgical protocol.

\section{References}

1. Müller H-D, Caballe-Serrano J, Lussi A, Gruber R. Inhibitory effect of saliva on osteoclastogenesis in vitro requires toll-like receptor 4 signaling. Clin Oral Investig. 2017; 21 (8): 2445-52. Available from: https://doi.org/10.1007/s00784-016-2041-7.

2. Ballantyne E. Bisphosphonates: possible modes of action and implications for dental implant treatment. A review of the literature. J Gen Pract. 2015; 192. Available from: https://doi. org/10.4172/2329-9126.1000192

3. Duyck J, Corpas L, Vermeiren S, Ogawa T, Quirynen M, Vandamme K Jacobs R, Naert I. Histological, histomorphometrical, and radiological evaluation of an experimental implant design with a high insertion torque. Clin Oral Implants Res. 2010; 21: 877-84. DOI: 10.1111/j.1600-0501.2010.01895.x

4. Bertollo N, Milne HRM, Ellis LP, Stephens PC, Gillies RM, Walsh WR. A comparison of the thermal properties of 2- and 3-fluted drills and the effects on bone cell viability and screw pull-out strength in an ovine model. Clin Biomech (Bristol, Avon). 2010; 25: 613-7.

5. Funato A, Ogawa T. Photofunctionalized dental implants: a case series in compromised bone. The International Journal of Oral \& Maxillofacial Implants. 2013; 28 (6): 1589-601. DOI: 10.11607/jomi.3232.

6. Tonelli $\mathrm{P}$, Duvina $\mathrm{M}$, Barbato $\mathrm{L}$, et al. Bone regeneration in dentistry. Clin Cases Miner Bone Metab. 2011; 8 (3): 24-28.

7. Junker R, Dimakis A, Thoneick M, Jansen JA. Effects of implant surface coatings and composition on bone integration: a systematic review. Clinical Oral Implants Research. 2009; 20 (supplement 4): 185-206. DOI: 10.1111/j.1600-0501.2009.01777.x.

8. Insua A, Monje A, Wang HL, Miron RJ. Basis of bone metabolism around dental implants during osseointegration and peri-implant bone loss. J Biomed Mater Res A. 2017; 105 (7): 2075-89.

9. Calvo-Guirado JL, Ortiz-RuizAJ, NegriB, López-Marí L, RodriguezBarba C, Schlottig F. Histological and histomorphometric evaluation of immediate implant placement on a dog model with a new implant surface treatment. Clinical Oral Implants Research. 2010; 21 (3): 308-15. DOI: 10.1111/j.1600-0501.2009.01841.x.

10. Believskaya RR, Mingazeva AZ. Vliyanie ossein-gidroksiapatitnogo kompleksa na metabolizm kostnoy tkani pri dental'noy implantatsii. Problemy stomatologii. 2012; 5: 38-42. Russian.

11. Kiseleva IV, Strelnikov VN, Slyusar NN, Kochkurov OV. Novye podkhody k diagnostike sostoyaniya kostnoy tkani chelyustey u patsientov posle rekonstruktivnykh operatsiy i provedennoy implantatsii. Verkhnevolzhskiy meditsinskiy zhurnal. 2014; 12 (1): 30-32. Russian.

12. Gorobec SM, Romanenko IG, Dzhereley AA, i dr. Faktory riska razvitija vospalitel'nyh oslozhnenij dental'noj implantacii. Tavricheskij mediko-biologicheskij vestnik. 2017; 20 (2): 208-14. Russian.

13. Eriksson AR, Albrektsson T. Temperature threshold levels for heatinduced bone tissue injury: a vital-microscopic study in the rabbit. J Prosthet Dent. 1983; 50: 101-7.

14. Hillery M, Shuaibb I. Temperature effects in the drilling of human and bovine bone. J Mater Process Technol. 1999; 92: 302-8.

15. Le Guéhennec L, Soueidan A, Layrolle P, Amouriq Y. Surface treatments of titanium dental implants for rapid osseointegration. Dental Materials. 2017; 23 (7): 844-54. DOI: 10.1016/j. dental.2006.06.025.

16. Jablokov AE, Ivashhenko AV, Kondrashin DV, avtory, patentoobladateli. Stomatologicheskil robot. Patent RF \# 2700542. 17.09.2019. 17. Negri B. Bone regeneration in dentistry. Biomed Mater Res Part A. 2019; 110 (2): 116-29. Russian.

17. Negri B. Bone regeneration in dentistry. Biomed Mater Res Part A. 2019; 110 (2): 116-29.

18. Warnke PH, Voss E, Russo PAJ, et al. Antimicrobial peptide coating of dental implants: biocompatibility assessment of recombinant human beta defensin-2 for human cells. The International Journal of Oral \& Maxillofacial Implants. 2013; 28 (4): 982-8. DOI: 10.11607/jomi.2594.

19. Webster TJ, Ejiofor JU. Increased osteoblast adhesion on nanophase metals: Ti, Ti6Al4V, and CoCrMo. Biomaterials. 2014; 25 (19): 4731-9. DOI: 10.1016/j.biomaterials.2014.12.002. 


\section{Литература}

1. Müller H-D, Caballe-Serrano J, Lussi A, Gruber R. Inhibitory effect of saliva on osteoclastogenesis in vitro requires toll-like receptor 4 signaling. Clin Oral Investig. 2017; 21 (8): 2445-52. Available from: https://doi.org/10.1007/s00784-016-2041-7.

2. Ballantyne E. Bisphosphonates: possible modes of action and implications for dental implant treatment. A review of the literature. J Gen Pract. 2015; 192. Available from: https://doi. org/10.4172/2329-9126.1000192

3. Duyck J, Corpas L, Vermeiren S, Ogawa T, Quirynen M, Vandamme K, Jacobs R, Naert I. Histological, histomorphometrical, and radiological evaluation of an experimental implant design with a high insertion torque. Clin Oral Implants Res. 2010; 21: 877-84. DOI: 10.1111/j.1600-0501.2010.01895.x.

4. Bertollo N, Milne HRM, Ellis LP, Stephens PC, Gillies RM, Walsh WR. A comparison of the thermal properties of 2- and 3-fluted drills and the effects on bone cell viability and screw pull-out strength in an ovine model. Clin Biomech (Bristol, Avon). 2010; 25: 613-7.

5. Funato A, Ogawa T. Photofunctionalized dental implants: a case series in compromised bone. The International Journal of Oral \& Maxillofacial Implants. 2013; 28 (6): 1589-601. DOI: 10.11607/ jomi.3232.

6. Tonelli $\mathrm{P}$, Duvina $\mathrm{M}$, Barbato $\mathrm{L}$, et al. Bone regeneration in dentistry. Clin Cases Miner Bone Metab. 2011; 8 (3): 24-28.

7. Junker R, Dimakis A, Thoneick M, Jansen JA. Effects of implant surface coatings and composition on bone integration: a systematic review. Clinical Oral Implants Research. 2009; 20 (supplement 4): 185-206. DOI: 10.1111/j.1600-0501.2009.01777.x.

8. Insua A, Monje A, Wang HL, Miron RJ. Basis of bone metabolism around dental implants during osseointegration and peri-implant bone loss. J Biomed Mater Res A. 2017; 105 (7): 2075-89.

9. Calvo-Guirado JL, Ortiz-RuizAJ, NegriB, López-MaríL, RodriguezBarba C, Schlottig F. Histological and histomorphometric evaluation of immediate implant placement on a dog model with a new implant surface treatment. Clinical Oral Implants Research. 2010; 21 (3): 308-15. DOI: 10.1111/j.1600-0501.2009.01841.x.
10. Белиевская Р. Р., Мингазева А. З. Влияние оссеингидроксиапатитного комплекса на метаболизм костной ткани при дентальной имплантации. Проблемы стоматологии. 2012; 5: 38-42.

11. Киселева И. В., Стрельников В. Н., Слюсарь Н. Н., Кочкуров О. В. Новые подходы к диагностике состояния костной ткани челюстей у пациентов после реконструктивных операций и проведенной имплантации. Верхневолжский медицинский журнал. 2014; 12 (1): 30-32.

12. Горобец С. М., Романенко И. Г., Джерелей А. А. и др. Факторы риска развития воспалительных осложнений дентальной имплантации. Таврический медико-биологический вестник. 2017; 20 (2): 208-14.

13. Eriksson AR, Albrektsson T. Temperature threshold levels for heatinduced bone tissue injury: a vital-microscopic study in the rabbit. $J$ Prosthet Dent. 1983; 50: 101-7.

14. Hillery M, Shuaibb I. Temperature effects in the drilling of human and bovine bone. J Mater Process Technol. 1999; 92: 302-8.

15. Le Guéhennec L, Soueidan A, Layrolle P, Amouriq Y. Surface treatments of titanium dental implants for rapid osseointegration. Dental Materials. 2017; 23 (7): 844-54. DOI: 10.1016/j. dental.2006.06.025.

16. Яблоков А. Е., Иващенко А. В., Кондрашин Д. В., авторы, патентообладатели. Стоматологический робот. Патент РФ № 2700542. 17.09.2019.

17. Negri B. Bone regeneration in dentistry. Biomed Mater Res Part A. 2019; 110 (2): 116-29.

18. Warnke PH, Voss E, Russo PAJ, et al. Antimicrobial peptide coating of dental implants: biocompatibility assessment of recombinant human beta defensin-2 for human cells. The International Journal of Oral \& Maxillofacial Implants. 2013; 28 (4): 982-8. DOI: 10.11607/jomi.2594.

19. Webster TJ, Ejiofor JU. Increased osteoblast adhesion on nanophase metals: Ti, Ti6Al4V, and CoCrMo. Biomaterials. 2014; 25 (19): 4731-9. DOI: 10.1016/j.biomaterials.2014.12.002. 